\title{
The Profile of Abundant and Essential Fatty Acids in Depot Fat Varies More in Kiwi (Apteryx mantelli) than in Other Avian Species
}

\author{
Murray Alan Potter ${ }^{1}$, Charlotte Jane Minson ${ }^{1}$, Roger Graham Lentle ${ }^{2}$ \\ ${ }^{1}$ Ecology Group, Institute of Agriculture and Environment, Massey University, Palmerston North, New Zealand; ${ }^{2}$ Institute of Food, \\ Nutrition and Human Health, Massey University, Palmerston North, New Zealand. \\ Email: m.potter@massey.ac.nz
}

Received June $28^{\text {th }}$, 2013; revised July $28^{\text {th }}, 2013$; accepted August $5^{\text {th }}, 2013$

Copyright (C) 2013 Murray Alan Potter et al. This is an open access article distributed under the Creative Commons Attribution License, which permits unrestricted use, distribution, and reproduction in any medium, provided the original work is properly cited.

\begin{abstract}
Direct and dendrographic comparison of the profiles of abundant fatty acids in depot fat was unable to separate 10 avian species on a basis of their overall proportions but was able to distinguish broad dietary groups or those in a habitat with distinctive nutritional characteristics such as avian marine carnivores. In all species considered, including North Island brown kiwi (Apteryx mantelli), oleic (C18:1) and palmitic acids (C16:0) were most abundant. The relative proportions of linolenic (C18:3) acid were 4\% or lower across all species, while the relative proportions of palmitoleic acid (C18:0) were less than $7 \%$ in nine of the avian species, with the exception being the insectivorous red-eyed vireo (Vireo olivaceous). The levels of linoleic acid (C18:2) were lower in avian marine carnivores than in avian herbivores, insectivores, and omnivores. Whilst the mean values of the individual fatty acids in fat from various avian species were separated by hierarchical cluster analysis, the wide range of values of each fatty acid precluded any correlation of clustering with any known variation in dietary items. Similarly, the wide range in fatty acid composition of kiwi fat rendered it unhelpful in determining the optimum composition of the captive diet.
\end{abstract}

Keywords: Fatty Acids; Composition; Depot Fat; Diet; Apteryx mantelli; Avian

\section{Introduction}

Fatty acids, the main constituent of most dietary lipids, are released from ingested fat molecules such as triacylglycerols during digestion but are not degraded before storage [1]. This relative resistance to degradation has led to the use of fatty acid analyses of fat depots to infer dietary intake. Such inference would be of value in determining the natural diets of threatened or cryptic species such as wild North Island brown kiwi (Apteryx mantelli).

The merit of this technique has been widely debated in the literature. The majority of studies, based largely on mammalian species, conclude that the method may provide a useful indicator of diet [1-6]. Evidence for this comes from demonstration that the fatty acid composition of the depot fat of pigs [7] and rats [8] is influenced by changes in dietary constituents. It would be expected that the method would be particularly useful in avian species as they rely principally on fats as a source of energy [9]. This conclusion is supported by work showing that the fatty acid composition of the adipose tissue of red grouse (Lagopus lagopus scotica) reflected that of its main food plants [10]. Similarly, the relative proportions of fatty acids in the depot fat of Adelie penguins (Pygoscelis adeliae) were reported to correspond to that of their normal diet [11].

Other evidence indicated that fatty acid profiles differ in some respects from those in the diet e.g. in cattle and sheep [12]. Indices of unsaturation of whole body fat content have been reported to differ from those of the diets in a range of birds including herring gulls (Larus argentatus), skuas (Megalestris catarrhactes), gannets (Sula bassana), and fulmar petrels (Fulmarus glacialis) [13]. In white crowned sparrow (Zonotrichia leucophrys gambelii) carcasses the proportions of linoleic and linolenic acids were found to be lower than in the diet, but the proportions of saturated and monounsaturated 16 and 18 carbon fatty acids higher than in the diet [14]. Similarly, the relative proportion of myristic acid in the depot fat of redpolls (Acanthis flammea) was greater than that 
in their natural diet [15].

A number of confounding factors may account for the latter discrepancies. There may be variation in fatty acid composition with site of sampling as was observed in pigs where fatty acid composition showed greater fluctuation with diet in back fat than in intramuscular fat [16]. Such variation may have resulted in part from the order of deposition and in the turnover at particular sites. In avian species, fats were found to be deposited initially in subcutaneous tissues and latterly in the furcular (clavicocoracoid), interfurcular and abdominal regions [9]. Similarly the turnover of dietary fats in humans varies with the site of deposition $[17,18]$, with the composition of subcutaneous fat reflecting short-term variation in dietary intake ( $<4$ weeks) and that of intra-abdominal fat reflecting long-term ( $>4$ weeks) intake [19].

Local variation in fatty acid composition of fat stores may also result from preferential storage of particular fats at particular sites. Hence the degree of unsaturation of dietary fatty acids was reported to influence the site at which they were stored and subsequently utilised [16]. Such preferential deposition could result in energy-rich substrates being stored at sites of particularly high activity and energy poor substrates being stored at sites of low activity. Hence, in chickens, relatively higher ratios of mono-unsaturated to polyunsaturated fats were found in abdominal than in muscle fat [17]. All of these discrepancies in fatty acid storage are likely to be influenced by changes in turnover at times when metabolic requirements are increased and hence may change with the level of volancy, season, and reproductive status [15].

Here, we survey published work regarding the fatty acid profiles in the storage fats of avian species and compare them directly with data obtained by us from gizzard fat of wild North Island brown kiwi. We also investigate whether species can be separated on a basis of the relative proportions of the more common fatty acids or on a basis of their diet.

\section{Materials and Methods}

We surveyed the literature for reports of the relative proportions of four of the most common fatty acids (palmitic, palmitoleic, stearic, oleic acids), and those of two essential fatty acids (linoleic and linolenic acid) in depot fat in avian species of known dietary habit (for references see Table 1). These results were combined with those from our analyses of the gizzard fat from the carcasses of adult North Island brown kiwi. The causes of death of these birds included accidental trapping, injury from motor vehicles, and predation. The carcasses were received in varying states of decomposition. The abdominal cavities of all birds had been opened on receipt and fat samples taken from the serosal surface of the gizzards as part of a prior investigation [20]. For the purposes of the current work the gizzard fat was dried at

Table 1. Comparison of the mean proportions of various fatty acids (as a percentage of the total fatty acid content) in the body fat of various avian species with different dietary habits. Ranges are given in brackets after value. Species names, the type of fat analyzed, sample sizes, and references are indicated in the footnotes. Species classified as insectivores may also consume seeds and/or crustaceans. Data are for adult birds unless otherwise stated.

\begin{tabular}{|c|c|c|c|c|c|c|c|}
\hline \multirow{2}{*}{ Dietary habit } & \multirow{2}{*}{ Species } & \multicolumn{6}{|c|}{ Fatty Acid } \\
\hline & & Palmitic & Palmitoleic & Stearic & Oleic & Linoleic & Linolenic \\
\hline Herbivore & Black grouse $^{\mathrm{a}}$ & $19(16-22)$ & $3(2-3)$ & $7(6-8)$ & $42(34-51)$ & $21(14-29)$ & $4(2-6)$ \\
\hline \multirow[t]{2}{*}{ Omnivore } & Canada geese ${ }^{* b}$ & $22(17-25)$ & $3(3-4)$ & $5(4-5)$ & $46(34-55)$ & $20(13-30)$ & $4(1-12)$ \\
\hline & Mallard ${ }^{*_{c}}$ & $20(16-24)$ & $3(2-4)$ & $7(6-9)$ & $48(42-57)$ & $19(15-24)$ & $2(1-3)$ \\
\hline \multirow[t]{3}{*}{ Insectivore } & Kiwi $^{\text {d }}$ & $20(13-28)$ & $2(1-4)$ & $10(4-20)$ & $43(24-58)$ & $10(5-19)$ & $2(0.3-8)$ \\
\hline & Red-eyed vireo $^{\mathrm{e}}$ & 18 & 28 & 3 & 33 & 16 & 2 \\
\hline & White-throated sparrow ${ }^{\mathrm{f}}$ & $16(12-22)$ & $3(2-5)$ & $6(6-7)$ & $35(34-37)$ & $33(24-40)$ & $4(3-4)$ \\
\hline \multirow{3}{*}{ Marine carnivore } & Northern fulmar ${ }^{*} \mathrm{~g}$ & $9(9-10)$ & $4(3-4)$ & $3(3-3)$ & $17(10-22)$ & $1(1-1)$ & $0.4(0.2-1)$ \\
\hline & Great-winged petrel $^{*_{\mathrm{i}}}$ & $15(13-18)$ & $5(4-6)$ & $4(2-6)$ & $41(40-41)$ & $2(2-3)$ & 0.3 \\
\hline & Semi-palmated sandpiper ${ }^{* j}$ & 27 & 7 & 8 & 23 & 4 & 2 \\
\hline
\end{tabular}

*Denotes migratory species; ${ }^{\mathrm{a}}$ Tetrao tetrix; crop, heart and gizzard fat; 2 [28]; ${ }^{\mathrm{b}}$ Branta canadensis; visceral fat (posterior to the gizzard); 22 [29]; 'Anas platyrhynchos; peritoneal fat; 75 [30]; ${ }^{\mathrm{d}}$ Apteryx mantelli; gizzard fat; 14 [this study]; and, subcutaneous fat; 1 [22]; ${ }^{\mathrm{e}}$ Vireo olivaceus; subcutaneous fat; 22 [31]; ${ }^{\mathrm{t}}$ Zonotrichia albicollis; adipose fat; 68 [32]; ${ }^{\mathrm{g}}$ Fulmaris glacialis; adipose fat; 101 [33]; ${ }^{\mathrm{h}}$ Puffinus pacificus; adipose fat; 2 chicks [34]; ${ }^{\mathrm{i}}$ Pterodroma macroptera; adipose fat; 2 chicks [34]; ${ }^{j}$ Calidris pusilla; subdermal fat; 3 [35]. 
$105^{\circ} \mathrm{C}$ in a convection oven (Watvic) and fats extracted with $60 / 80$ petroleum spirit. The fats were then methyllated and relative proportions of fatty acids determined following separation by gas chromatography as areas under the curve relative to a standard [21]. All analyses were conducted at the Nutrition Laboratory, Massey University, Palmerston North, New Zealand.

Data on the fatty acid composition of kiwi gizzard depot fat obtained from this study were compared with data obtained for subcutaneous fat from one North Island brown kiwi and partial data for breast fat from a second North Island brown kiwi, both reported in Shorland and Gass [22].

Statistical comparison of results between species was complicated by the fact that a number of the studies did not report data for individual birds and that sample size varied greatly between studies, there being generally insufficient data to determine distribution and homogeneity of variance (see Table 1). Further, the various methodologies for quantifying fatty acids also varied between studies. Consequently we compared data by hierarchical cluster analysis [23] computed on a basis of Euclidian distance (root mean squared distances) using SYSTAT version 12 [24]. Euclidean distance is considered most suitable for separation based on quantitative variables [25]. Divisions between groups were calculated on a basis of their un-weighted pair group means (UPGMA) using Ward's algorithm [26]. Ward's method is a UPGMA algorithm in which the Euclidean distances between all of the pairs of objects in different clusters is averaged to determine the distance between the respective clusters [27].

The clustering hierarchy obtained was examined from the viewpoint of its ability to separate species on a basis of their reported diet.

\section{Results}

\subsection{Kiwi}

The median, upper and lower quartile, and outlier data for palmitic, palmitoleic, stearic, oleic, linoleic and linolenic fatty acids as percentages of the total fatty acid content of 14 North Island brown kiwi gizzards are presented in Figure 1 along with the values from an individual kiwi for the same fatty acids in subcutaneous fat reported by Shorland and Gass [22]. These authors also presented data for the percentages of three fatty acids in the breast fat of another kiwi (data not included in Figure 1): palmitic $17.5 \%$; palmitoleic $2.9 \%$; stearic $7.5 \%$. For all but stearic acid (where the value was lower), the

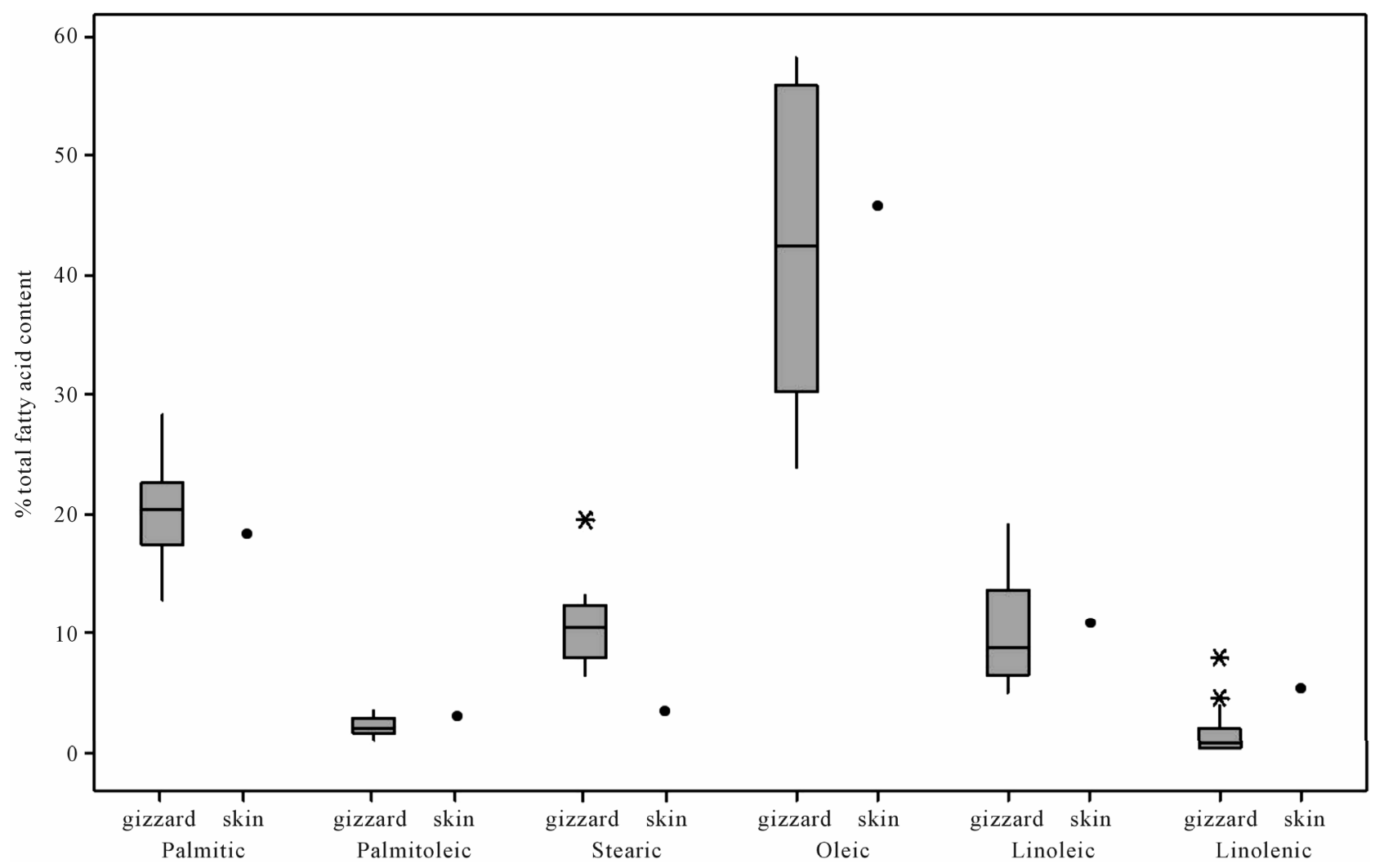

Figure 1. Box-plots of the palmitic, palmitoleic, stearic, oleic, linoleic and linolenic acid content of depot fat in kiwi gizzards (this study) and in skin [22]. 
values presented by Shorland and Gass [22] fell within the ranges we measured in kiwi gizzard fat.

\subsection{Simple Quantitative Comparison across Species}

Data obtained from the literature on relative proportions of palmitic, palmitoleic, stearic, oleic, linoleic and linolenic acids in depot fat of nine avian species of known dietary habit were compared with those of North Island brown kiwi (Table 1). The mean proportions of oleic and palmitic acids in kiwi fat were higher than those of palmitoleic, stearic, linoleic and linolenic acid. The same trend was common in fat from all species except black grouse (Tetrao tetrix) and white-throated sparrow (Zonotrichia albicollis) in which mean proportions of linoleic acid exceeded those of palmitic acid. The mean ratio of linoleic to linolenic acid in kiwi fat was 5:1, which was similar to that in fat from black grouse and Canada geese (Branta canadensis). The proportions of stearic and linolenic acids relative to those of the other fatty acids were low in all avian species analyzed. The relative proportion of linoleic acid was lower in the depot fat of avian marine carnivores than in that of avian species of other dietary habit. The relative proportion of palmitoleic acid was higher in fat from red-eyed vireos (Vireo olivaceus) than in fat from other species.

The magnitudes of the ranges in values of each fatty acid across individual birds were greater in kiwi than in any of the other species for all but linoleic acid where kiwi ranked third behind Canada geese and whitethroated sparrows.

\subsection{Dendrographic Analyses}

The dendrographic analysis based on mean fatty acid proportions separated the 10 avian species into two main clusters (Figure 2), with the group comprising a passerine insectivore (vireo) and three marine carnivores (sandpiper (Calidris pusilla), shearwater (Puffinus pacificus) and fulmar (Fulmarus glacialis)) separating markedly (Euclidean distance between groups 28) from the remaining species. The mean fatty acid profile of the vireo depot fat was separated from those of the remainder of the first group at a Euclidean distance of 16. The mean fatty acid profiles of the petrel and kiwi were separated from those of the remaining species in the second group at a distance of 13 . Those of the remaining species in the second group were separated by a Euclidean distance of 10 .

\section{Discussion}

\subsection{Non-Essential Fatty Acids}

The consistently high proportions of palmitic and oleic acids, across the range of avian species that were evalu-

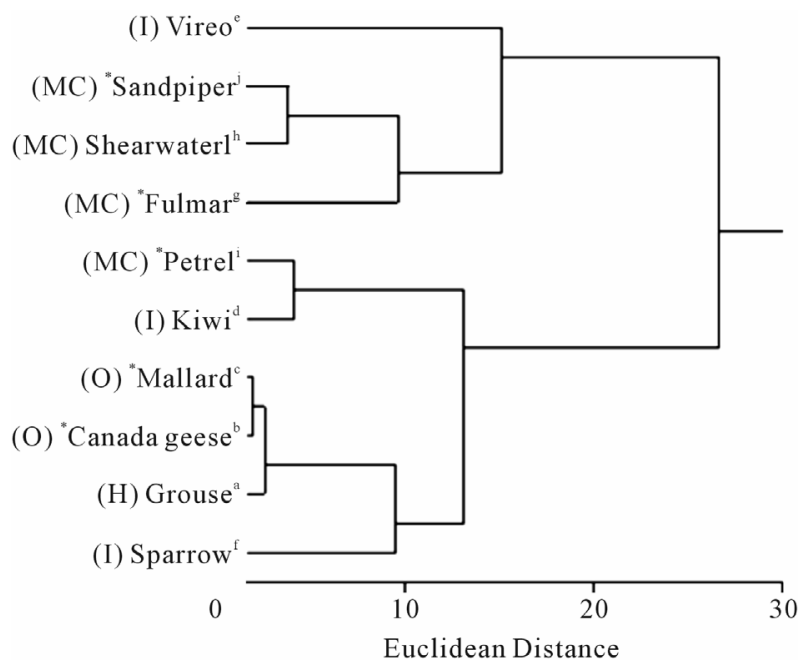

Figure 2. Dendrogram of the mean palmitic, palmitoleic, stearic, oleic, linoleic and linolenic acid proportions in body fat of various avian species. $\mathrm{MC}=$ marine carnivore; $\mathbf{I}=$ insectivore (the vireo and white-throated sparrow may also consume seeds and berries); $\mathbf{O}=$ omnivore; $\mathbf{H}=$ herbivore; * = migratory. See Table 1 footnote for details of species names, the type of fat analyzed, sample sizes, and references.

ated, are consistent with the high proportions reported in other taxa [11]. Both of these fatty acids are readily synthesized endogenously in most species and thus their proportions are less likely to reflect diet. Palmitic acid is the most abundant fatty acid in eukaryotes [10]. It is the primary product of long-chain fatty acid synthesis in both plants and animals and is readily converted by desaturation or elongation into a variety of fatty acids [11]. Oleic acid is the most common unsaturated fatty acid and is the precursor for the production of other polyunsaturated fatty acids [11].

With the exception of vireos, both stearic and palmitoleic acids were found in low levels in depot fat of all 10 avian species examined irrespective of their diet. Apart from ruminants, that have characteristically high levels of stearate in their depot fat [8], stearic acid is generally found in lower proportions in depot fat as it is rapidly converted by desaturation into oleic acid [7]. Palmitoleic acid is generally a minor component of animal and vegetable fats, although some fish, seed oils and invertebrates contain substantial quantities [11] [Potter, unpublished data]. The relatively high level of palmitoleic acid found in red-eyed vireo fat is likely to be due to its insectivorous diet [36].

The fatty acid profiles of gannets, fulmars, skua gulls and herring gulls are similar to those in most marine fish [13]. The fatty acid profiles in the herbivorous, omnivorous and insectivorous species examined were generally similar. 
Strongly migratory birds have been reported to accumulate greater proportions of unsaturated fatty acids in their fat stores [37-39] which may be of advantage during the metabolic demands of migration [40]. Other work reported the contrary showing no change in the proportion of unsaturated acids in the periods leading up to, during, and post migratory phases [23,41]. The results of this study support the latter finding in showing that there is no greater proportion of unsaturated fatty acids in the fat stores of migratory than in non-migratory birds. Moreover, the fat of non-migratory insectivorous species had generally higher oleic acid levels than those of the marine carnivorous birds that are likely to require higher fat stores in order to fly greater distances.

\subsection{Essential Fatty Acids}

Linoleic (omega 6) and linolenic (omega 3) fatty acids, cannot be synthesized by animals and must be sourced directly from the diet [42]. Linoleic acid is found in quantity in most seeds and seed oils [43] and linolenic acid is the main fatty acid in leafy material [44], algae and phytoplankton [45]. The level of linolenic acid in the depot fat of most animals is generally low [46].

It may therefore be considered that the levels of linoleic and linolenic acids are more likely to reflect dietary intake than endogenously synthesizable fats. Sea birds are likely to exemplify this because their diets contain little or no metabolizable carbohydrate so they have little opportunity to synthesize fat [8]. It is possible, however, that stores of either essential fatty acid may become "diluted" when the birds store large quantities of common fatty acids for use during migration or hibernation. In this regard it is noteworthy that the compositions of fat stores in migratory birds are reported to differ from those of non-migratory birds [47] on a basis of the ratio of an abundant to an essential fatty acid. Hence migratory birds are reported to store more oleic acid relative to linoleic acid than their non-migrant counterparts [9]. However, the results of this study did not show any separation based on this pattern.

\subsection{Dendrographic Analyses}

The dendrogram of the proportions of palmitic, palmitoleic, stearic, oleic, linoleic and linolenic acids in body fat separated three of the four marine carnivores and an insectivore into one of the main divisions, and the remaining marine carnivore and the other avian species into the second division. Even though the insectivorous vireo separated with the main group of marine carnivores it then separated further into a solo group. The high palmitoleic acid content of the depot fat of vireo compared with the other insectivorous species is likely to have effected this separation. The separation of the marine carnivores across the main division likely indicates that these species have a widely varied dietary intake.

It is interesting that relative proportions of fatty acids in the fat of the three avian insectivores separated so widely on the dendrogram. While we classified both the red-eyed vireo and the white-throated sparrow as insectivores, it is noteworthy that the diet of the former changes from insects to fruit in fall [48], and the diet of the latter includes seeds and berries throughout the year [32]. This is likely reflected in the fatty acid composition of their depot fat. Similarly, while the diet of kiwi comprises at least $90 \%$ invertebrates, the remaining $10 \%$ comprises seeds and fruit [49].

In this study we have focused on avian species, but comparisons with relevant mammalian species are useful. The fatty acid composition of the echidna, a monotreme insectivore [50], differs markedly from that reported here for kiwi. The very high levels of oleic acid in echidnas are likely due to their consumption of ants and termites, insects that are not consumed by kiwi.

The fatty acid composition of insect fat varies markedly across taxa [51] and can change with age, season, and location [14]. That of fruit varies markedly between species [52]. This, along with the catholic dietary habits of wild kiwi and a tendency for them to feast on dietary items when abundant [49], is the likely cause of the wide variation in fatty acid composition of their adipose tissue. While such variation renders their depot fat a poor indicator of dietary intake, their catholic habits are manifest in their acceptance of a range of different diets in captivity [53].

Whilst this study is the first to provide details of the fatty acid profile of the depot fat of North Island brown kiwi, it also indicates that the wide variation in its composition across individuals renders it unhelpful in determining the optimum composition of the captive diet.

\section{Acknowledgements}

We thank Nikki Pindur for sourcing the kiwi gizzard fat samples. Funding support was received from the Bank of New Zealand Kiwi Recovery Trust, the Institute of Natural Resources, Massey University, and the Institute of Food, Nutrition and Hunan Health, Massey University. C. J. M. received a Massey University Doctoral Scholarship.

\section{REFERENCES}

[1] S. J. Iverson, C. Field, W. D. Bowen and W. Blanchard, "Quantitative Fatty Acid Signature Analysis: A New Method of Estimating Predator Diets,” Ecological Monographs, Vol. 74, No. 2, 2004, pp. 211-235. 
doi:10.1890/02-4105

[2] O. Grahl-Nielsen and O. Mjaavatten, "Dietary Influence on Fatty Acid Composition of Blubber Fat of Seals as Determined by Biopsy: A Multivariate Approach,” Marine Biology, Vol. 110, No. 1, 1991, pp. 59-64. doi:10.1007/BF01313092

[3] M. J. Walton, R. J. Henderson and P. P. Pomeroy, "Use of Blubber Fatty Acid Profiles to Distinguish Dietary Differences between Grey Seals Halichoerus grypus from Two UK Breeding Colonies,” Marine Ecology Progress Series, Vol. 193, 2000, pp. 201-208. doi:10.3354/meps193201

[4] O. Grahl-Nielsen, M. Andersen, A. E. Derocher, C. Lydersen, O. Wiig and K. M. Kovacs, "Fatty Acid Composition of the Adipose Tissue of Polar Bears and of Their Prey: Ringed Seals, Bearded Seals and Harp Seals,” Marine Ecology Progress Series, Vol. 265, 2003, pp. 275- 282. doi:10.3354/meps265275

[5] B. C. McMeans, M. T. Arts and A. T. Fisk, "Similarity between Predator and Prey Fatty Acid Profiles Is Tissue Dependent in Greenland Sharks (Somniosus microcephalus): Implications for Diet Reconstruction,” Journal of Experimental Marine Biology and Ecology, Vol. 429, 2012, pp. 55-63. doi:10.1016/j.jembe.2012.06.017

[6] L. Meynier, P. C. H. Morel, B. L. Chilvers, D. D. S. Mackenzie and P. J. Duignan, "Quantitative Fatty Acid Signature Analysis on New Zealand Sea Lions: Model Sensitivity and Diet Estimates," Journal of Mammalogy, Vol. 91, No. 6, 2010, pp. 1484-1495. doi:10.1644/09-MAMM-A-299.1

[7] R. McPherson and G. A. Spiller, "Effects of Dietary Fatty Acids and Cholesterol on Cardiovascular Disease Risk Factors in Man,” In: G. A. Spiller, Ed., Handbook of Lipids in Human Nutrition, CRC Press, Inc., New York, 1996.

[8] T. P. Hilditch, "The Chemical Constitution of Natural Fats,” 3rd Edition, Chapman and Hall, London, 1956.

[9] C. R. Blem, "Patterns of Lipid Storage and Utilization in Birds,” American Zoologist, Vol. 16, No. 4, 1976, pp. 671-684.

[10] F. Lynen, "On the Structure of Fatty Acid Synthetase of Yeast,” European Journal of Biochemistry, Vol. 112, No. 3, 1980, pp. 431-442. doi:10.1111/j.1432-1033.1980.tb06105.x

[11] S. M. Watkins and J. B. German, "Omega Fatty Acids," In: C. C. Akoh and D. B. Min, Eds., Food Lipids, Marcel Dekker, Inc., New York, 1998.

[12] F. B. Shorland, "Effect of the Dietary Fat on the Composition of the Depot Fats of Animals," Nature, Vol. 165, No. 4202, 1950, p. 766. doi:10.1038/165766a0

[13] J. A. Lovern, “The Body Fats of Some Sea Birds,” Biochemical Journal, Vol. 32, No. 12, 1938, pp. 2142-2144.

[14] S. J. Turunen, "Lipid Utilization in Adult Pieris brassicae with Special Reference to the Role of Linoleic Acid," Journal of Insect Physiology Vol. 20, No. 7, 1974, pp. 1257-1269. doi:10.1016/0022-1910(74)90231-5

[15] G. C. West and M. S. Meng, "The Effect of Diet and
Captivity on the Fatty Acid Composition of Redpoll (Acanthis flammea) Depot Fats," Comparative Biochemistry and Physiology, Vol. 25, No. 2, 1968, pp. 535-540. doi:10.1016/0010-406X(68)90364-2

[16] D. E. Koch, A. F. Parr and R. A. Merkel, "Fatty Acid Composition of the Inner and Outer Layers of Porcine Backfat as Affected by Energy Level, Sex and Sire,” Journal of Food Science, Vol. 33, No. 2, 1968, pp. 176-180. doi:10.1111/j.1365-2621.1968.tb01345.x

[17] S. D. Phinney, J. S. Stern, K. E. Burke, A. B. Tang, G. Miller and R. T. Holman, "Human Subcutaneous Adipose Tissue Shows Site-Specific Differences in Fatty Acid Composition," American Journal of Clinical Nutrition, Vol. 60, No. 5, 1994, pp. 725-729.

[18] M. Garaulet, F. Perez-Llamas, M. Perez-Ayala, P. Martinez, F. S. de Medina, F. J. Tebar and S. Zamora, "SiteSpecific Differences in the Fatty Acid Composition of Abdominal Adipose Tissue in an Obese Population from a Mediterranean Area," American Journal of Clinical Nutrition, Vol. 74, 2001, pp. 585-591.

[19] A. C. Guyton and J. E. Hall, "Textbook of Medical Physiology,” Saunders Company, Philadelphia, 1996.

[20] N. B. Pindur, "Gut Morphology and Nutrient Composition of Diets in Wild and Captive North Island Brown Kiwi (Apteryx mantelli),” MSc Thesis, Massey University, Palmerston North, 2004.

[21] G. C. West and M. S. Meng, "Seasonal Changes in Body Weight and Fat and the Relation of Fatty Acid Composition to Diet in the Willow Ptarmigan,” The Wilson Bulletin, Vol. 80, No. 4, 1968, pp. 426-441.

[22] F. B. Shorland and J. P. Gass, "Fatty Acid Composition of the Depot Fats of the Kiwi (Apteryx australis mantelli)," Journal of the Science of Food and Agriculture, Vol. 12, No. 3, 1961, pp. 174-177. doi:10.1002/jsfa.2740120302

[23] R. D. McGreal and D. S. Farner, "Premigratory Fat Deposition in the Gambel Whitecrowned Sparrow," Northwest Science, Vol. 30, 1956, pp. 12-23.

[24] Systat Software Inc, "SYSTAT 11: Statistical Software Package,” Systat Software Inc., Chicago, 2004.

[25] M. Chavent, “A Monothetic Clustering Method,” Pattern Recognition Letters, Vol. 19, No. 11, 1998, pp. 989-996. doi:10.1016/S0167-8655(98)00087-7

[26] J. H. Ward, "Hierarchical Grouping to Optimize an Objective Function," Journal of the American Statistical Association, Vol. 58, No. 301, 1963, pp. 236-244. doi:10.1080/01621459.1963.10500845

[27] J. D. Jobson, “Applied Multivariate Data Analysis: Categorical and Multivariate Methods," Vol. 2, SpringerVerlag, New York, 1992. doi:10.1007/978-1-4612-0921-8

[28] R. Moss and A. K. Lough, "Fatty Acid Composition of Depot Fats in Some Game Birds (Tetraonidae)," Comparative Biochemistry and Physiology, Vol. 25, No. 2, 1968, pp. 559-562. doi:10.1016/0010-406X(68)90368-X

[29] V. G. Thomas and J. C. George, "Plasma and Depot Fat Fatty Acids in Canada Geese in Relation to Diet, Migra- 
tion, and Reproduction,” Physiological Zoology, Vol. 48, No. 2, 1975, pp. 157-167.

[30] M. E. Heitmeyer and L. H. Fredrickson, "Fatty Acid Composition of Wintering Female Mallards in Relation to Nutrient Use," The Journal of Wildlife Management, Vol. 54, No. 1, 1990, pp. 54-61. doi:10.2307/3808900

[31] B. Pierce, S. R. McWilliams, A. R. Place and M. A. Huguenin, "Diet Preferences for Specific Fatty Acids and Their Effect on Composition of Fat Reserves in Migratory Red-Eyed Vireos (Vireo olivaceous)," Comparative Biochemistry and Physiology-Part A: Molecular \& Integrative Physiology, Vol. 138, No. 4, 2004, pp. 503-514. doi:10.1016/j.cbpb.2004.06.014

[32] J. M. Klaiman, E. R. Price and C. G. Guglielmo, "Fatty Acid Composition of Pectoralis Muscle Membrane, Intramuscular Fat Stores and Adipose Tissue of Migrant and Wintering White-Throated Sparrows (Zonotrichia albicollis)," Journal of Experimental Biology, Vol. 212, No. 23, 2009, pp. 3865-3872. doi:10.1242/jeb.034967

[33] S. Wang, S. Iverson, A. Springer and S. Hatch, "Fatty Acid Signatures of Stomach Oil and Adipose Tissue of Northern Fulmars (Fulmarus glacialis) in Alaska: Implications for Diet Analysis of Procellariiform Birds," Journal of Comparative Physiology B: Biochemical, Systemic, and Environmental Physiology, Vol. 177, No. 8, 2007, pp. 893-903. doi:10.1007/s00360-007-0187-y

[34] C. C. Cheah and I. A. Hansen, "Stomach Oil and Tissue Lipids of the Petrels Puffinus pacificus and Pterodroma macroptera," International Journal of Biochemistry, Vol. 1, No. 2, 1970, pp. 203-208. doi:10.1016/0020-711X(70)90095-9

[35] G. E. Napolitano and R. G. Ackman, “Anatomical Distribution of Lipids and Their Fatty Acids in the Semipalmated Sandpiper Calidris pusilla L. from Shepody Bay, New Brunswick, Canada," Journal of Experimental Marine Biology and Ecology, Vol. 144, No. 2-3, 1990, pp. 113-124. doi:10.1016/0022-0981(90)90023-6

[36] P. Williamson, "Feeding Ecology of the Red-Eyed Vireo (Vireo olivaceus) and Associated Foliage-Gleaning Birds,” Ecological Monographs, Vol. 41, No. 2, 1971, pp. 129-152. doi:10.2307/1942388

[37] F. Bairlein and E. Gwinner, "Nutritional Mechanisms and Temporal Control of Migratory Energy Accumulation in Birds,” Annual Review of Nutrition, Vol. 14, No. 1, 1994, pp. 187-215. doi:10.1146/annurev.nu.14.070194.001155

[38] J.-M. Weber, "The Physiology of Long-Distance Migration: Extending the Limits of Endurance Metabolism," Journal of Experimental Biology, Vol. 212, 2009, pp. 593-597. doi:10.1242/jeb.015024

[39] E. R. Price, A. Krokfors and C. G. Guglielmo, "Selective Mobilization of Fatty Acids from Adipose Tissue in Migratory Birds," Journal of Experimental Biology, Vol. 211, 2008, pp. 29-34. doi:10.1242/jeb.009340

[40] D. W. Johnston, "Cytological and Chemical Adaptations of Fat Deposition in Migratory Birds,” Condor, Vol. 75, No. 1, 1973, pp. 108-113. doi:10.2307/1366540
[41] D. L. Hicks, “Adipose Tissue Composition and Cell Size in Fall Migratory Thrushes (Turdidae)," The Condor, Vol. 69, No. 4, 1967, pp. 387-399. doi:10.2307/1366200

[42] A. A. Spector, "Lipid Metabolism: Essential Fatty Acids,” In: H. M. Stipanuk, Ed., Biochemical and Physiological Aspects of Human Nutrition, W. B. Saunders Company, New York, 2000, pp. 365-383.

[43] A. P. Simopoulos, "Part 1: Metabolic Effects of Omega-3 Fatty Acids and Essentiality,” In: G. A. Spiller, Ed., Handbook of Lipids in Human Nutrition, CRC Press, Inc., New York, 1996.

[44] L. Hartman and F. B. Shorland, "Fatty Acid Composition of the Depot Fats and Liver Lipids of the Takahe (Notornis mantelli)," New Zealand Journal of Science, Vol. 11, 1968, pp. 231-235.

[45] L. Chuecas and J. P. Riley, "Component Fatty Acids of the Total Lipids of Some Marine Phytoplankton,” Journal of the Marine Biological Association of the United Kingdom, Vol. 49, No. 1, 1969, pp. 97-116. doi:10.1017/S0025315400046439

[46] J. D. Wood and M. Enser, "Factors Influencing Fatty Acids in Meat and the Role of Antioxidants in Improving Meat Quality,” British Journal of Nutrition, Vol. 78, No. 1, 1997, pp. S49-S60. doi:10.1079/BJN19970134

[47] C. R. Blem, “Avian Energy Storage,” In: D. M. Power, Ed., Current Ornithology, Plenum Press, New York, 1990, pp. 59-113.

[48] D. A. Cimprich, F. R. Moore and M. P. Guilfoyle, "Red-Eyed Vireo," In: A. Poole and F. Gill, Eds., The Birds of North America, The Academy of Natural Sciences, PA and The American Ornithologists' Union, Washington DC, 2000, pp. 1-24.

[49] R. G. Kleinpaste, "Kiwis in a Pine Forest Habitat,” In: E. Fuller, Ed., Kiwis: A Monograph of the Family Apterygidae, Swan Hill Press, Shrewsbury, 1990, pp. 97-139. doi:10.1007/s003600000157

[50] F. Falkenstein, G. Kortner, K. Watson and F. Geiser, "Dietary Fats and Body Lipid Composition in Relation to Hibernation in Free-Ranging Echidnas," Journal of Comparative Physiology B, Vol. 171, 2001, pp. 189-194.

[51] D. W. Stanley-Samuelson, R. A. Jurenka, C. Cripps, G. J. Blomquist and M. de Renobales, "Fatty Acids in Insects: Composition, Metabolism, and Biological Significance," Archives of Insect Biochemistry and Physiology, Vol. 9, No. 1, 1988, pp. 1-33. doi:10.1002/arch.940090102

[52] Z. R. Wharemate, "Survey of the Fatty Acid Content of Native New Zealand Plants,” MSc Thesis, Massey University, Palmerston North, 2003.

[53] M. A. Potter, W. H. Hendriks, R. G. Lentle, D. V. Thomas, C. J. Minson and N. B. Pindur, "An Exploratory Analysis of the Suitability of Diets Fed to a Flightless Insectivore, the Kiwi (Apteryx mantelli), in New Zealand," Zoo Biology, Vol. 29, No. 5, 2010, pp. 537-550. doi:10.1002/zoo.20283 